\title{
社会における薬局薬剤師の役割に関する考察
}

\author{
林 誠一郎
}

\section{The Expected Role of Community Pharmacist in Society}

\author{
Sei-ichiro HAYASHI \\ Central Pharmaceutical Information Center, The Japan Pharmaceutical Association, \\ Nagai Memorial Building 4F, 2-12-15 Shibuya, Shibuya-ku, Tokyo 150-8389, Japan
}

(Received October 15, 2002; Accepted December 5, 2002)

\begin{abstract}
With recent advances in the separation of dispensing and prescribing drugs (Bungyo), the social role of community pharmacists has expanded. Therefore we carried out a questionnaire survey on the "image of community pharmacists" among patients/the public, physicians, and community pharmacists. The understanding of their role by community pharmacists differed slightly from that by patients/the public or physicians. Better mutual understanding among the three parties is necessary for smooth communication. Dispensing and handing over drugs to patients are not the only tasks required of community pharmacists. Evaluation of records of telephone drug counseling by the Japan Pharmaceutical Association revealed that many callers desired not only drug information but also the opinions and judgments of pharmacists. Providing drug information is an important task for community pharmacists. In addition, counseling on anxiety and worries about health may be necessary. Bungyo has also affected drug distribution. In this field, the role of community pharmacists in providing drug information may markedly change in the future.
\end{abstract}

Key words_-Bungyo; community pharmacist; image of community pharmacists; telephone drug counseling; correspondence analysis

緒

論

近年, 医薬分業の進渉は目覚ましく, 日本薬剤師 会の集計によれば平成 14 年 7 月の分業率は $47.2 \%$ にも達しているが，これに対する患者・市民の意見 は好意的になりつつある1) とは言え, 依然として賛 否両論である。医薬分業は社会における 1 つのシス テムであるから，社会的な合意（パブリック・アク セプタンス）が得られていることが大切である。す なわち, 医薬分業は単にメリット・デメリットの面 からだけではなく, 社会的視点からも検討されなけ ればならない。 そこで今回, 医薬分業の中心的役割 を担う薬局薬剤師に注目し, 社会におけるその役割 について考察することとした.

まず，患者・市民及び医師，さらには薬局薬剤師 に対して「薬局薬剤師のイメージ像」等を問うアン ケート調査を行い, 薬局薬剤師が日頃接する人々と の間に認識の隔たりがないかを検討した. 次に, 薬

日本薬剤師会中央薬事情報センター e-mail: hayashi@dd.mbn.or.jp
局薬剤師の患者・市民に対する活動の代表例である 「情報提供」と「心配・不安の相談」に着目し, マー ケティングの視点から, 薬局薬剤師職能の変化を考 察した. さらに, 医薬品流通に関する文献調査をも とに, 流通論の中での薬局薬剤師の存在意義を確認 した.

これらの結果は, 日本において医薬分業が進む 中, 薬局薬剤師が社会に認知されるための新たな視 点を提供するものと考える.

\section{調査と方法}

1.「薬局薬剤師のイメージ像」等に関するアン ケート調査

調査は, 患者・市民, 医師, 薬局薬剤師のそれぞ れに対して個別に行った.

患者・市民に対する調査は, 2001 年 2 月から 3 月において, 協力の得られた薬局の店頭において調 査票を配付し回答を郵送にて回収する方法, 及び協 和発酵工業株式会社（以下, 協和発酵とする.）の 社員・家族に調査票を配付し, 同社の事業所を経由 
Table 1. Comparison of "Image of Community Pharmacists" among Patients /the Public, Physicians and Community Pharmacists

\begin{tabular}{crrr}
\hline \hline & 患者・市民 & 医 師 & 薬局薬剤師 \\
\hline 薬の専門家 & $2415(46.5 \%)$ & $584(55.9 \%)$ & $675(43.0 \%)$ \\
医療人 & $327(6.3 \%)$ & $171(16.3 \%)$ & $722(46.0 \%)$ \\
薬を調剂する職人 & $1836(35.4 \%)$ & $213(20.4 \%)$ & $117(7.4 \%)$ \\
薬を扱う商人 & $610(11.8 \%)$ & $77(7.4 \%)$ & $56(3.6 \%)$ \\
\hline 合 計 & $5188(100 \%)$ & $1045(100 \%)$ & $1570(100 \%)$ \\
\hline
\end{tabular}

注：（）内の\%は, 患者・市民, 医師, 薬局薬剤師それぞれの合計に対する割合である.

Table 2. A Feeling of Reliability to Community Pharmacists among Patients/the Public, Physicians and Community Pharmacists

\begin{tabular}{|c|c|c|c|}
\hline & 患者・市民 & 医 師 & 薬局薬剤師 \\
\hline あまり信頼できない & $632(12.2 \%)$ & $73(7.0 \%)$ & $82(5.2 \%)$ \\
\hline まあまあ信頼できる & $3754(72.4 \%)$ & $633(60.6 \%)$ & $1326(84.5 \%)$ \\
\hline 十分信頼できる & $802(15.4 \%)$ & $339(32.4 \%)$ & $162(10.3 \%)$ \\
\hline 合計 & $5188(100 \%)$ & $1045(100 \%)$ & $1570(100 \%)$ \\
\hline
\end{tabular}

して回答を回収する方法によった．医師に対する調 查は, 2002 年 2 月において, 院外処方せんを発行 している病院・診療所を対象とし, 協和発酵の医薬 情報担当者が各施設の医師に調査票を持参し, 回答 は郵送にて回収する方法によった。薬局薬剤師に対 する調査は, 2000 年 12 月から 2001 年 1 月におい て, 協和発酵の薬局向け冊子「薬立つ話」No. 29 に調査票を同封し, 回答は主にファクシミリで回収 する方法によった.

患者・市民，医師，薬局薬剂師のそれぞれに対す る調査項目は複数にわたつたが, 今回報告するもの は, 三者に共通の調査項目である「薬局薬剤師のイ メージ像」と「薬局薬剤師への信頼感」についての 結果である. 前者については Table 1 に示す「薬の 専門家」などの四肢から, また, 後者については Table 2 に示す「あまり信頼できない」などの三肢 から，それぞれ最も近いものを 1 つ選択してもらつ た.

得られた回答は, Excel 2000 (Microsoft Corp.) にて統計処理を行った。 さらに，「薬局薬㓮師のイ メージ像」については, 多変量解析の 1 つであるコ レスポンデンス分析を行った. 分析の手順は, まず, Table 1 中の「患者・市民」「医師」「薬局薬剤師」 「薬の専門家」「医療人」「薬を調剤する職人」「薬を
扱う商人」の計 7 アイテムをカテゴリーとして, Excel 2000 のワークシート上の 1 行に配置した。 ま た, 個々の回答者(サンプル)の回答結果について, 各アイテムに該当する場合には“1”を，また該当 しない場合には“0”を割り当てた。すなわち, ど のサンプルにおいても, 「患者・市民, 医師, 薬局 薬剂師」のうちの 1 つが“1”となり，かつ「薬の 専門家，医療人，薬を調剂する職人，薬を扱う商 人」のうちの 1 つが“1”となるようなデー夕表を 作成した。 ついで, この表について, SAS Ver 6.12 (SAS Institute Inc.) を用いてコレスポンデンス分 析を実行し, 得られたカテゴリースコアを空間配置 して，それらの相対的位置関係を観察した。 コレス ポンデンス分析を選んだ理由は, データが数量で与 えられず，各分類項目に「該当する」「しない」と いう反応模様で与えられていること, また, 患者・ 市民, 医師, 薬局薬剂師の三者の関係を視覚的に把 握するためには本法が適すると判断したことによ る. 2)

\section{2. 日本薬剤師会の消費者電話薬相談における調} 査

電話薬相談は, 日本薬剂師会中央薬事情報セン ターにおいて, 平日の 9 時〜 17 時の間, 6 名の薬剂 師が交代で受け付けた。 患者・市民からの個々の相 
Table 3. Scores for Contents in Correspondence Analysis

\begin{tabular}{lrrrrr}
\hline \hline (説明率) & \multicolumn{1}{c}{$\begin{array}{c}\text { DIM1 } \\
29.20 \%\end{array}$} & $\begin{array}{c}\text { DIM2 } \\
21.43 \%\end{array}$ & $\begin{array}{c}\text { DIM3 } \\
20.00 \%\end{array}$ & \multicolumn{1}{c}{ DIM4 } & \multicolumn{1}{c}{ DIM5 } \\
\hline 医 師 & 0.17064 & -1.85558 & 0.00000 & 1.72740 & 0.10378 \\
薬局薬剤師 & 1.63736 & 0.39922 & 0.00000 & -0.37164 & 0.99581 \\
患者・市民 & -0.52987 & 0.25295 & -0.00000 & -0.23548 & -0.32226 \\
専門家 & -0.04424 & -0.77441 & -0.04163 & -0.72092 & 0.02691 \\
医療人 & 1.84983 & 0.61535 & -0.03895 & 0.57285 & -1.12503 \\
職 人 & -0.74768 & 0.74874 & -0.88896 & 0.69702 & 0.45472 \\
商 人 & -0.63900 & 0.63618 & 2.86133 & 0.59223 & 0.38863 \\
\hline
\end{tabular}

注 : Table 1 の元データ $(n=7803)$ についてコレスポンデンス分析を行つた結果.

今回は, 第 5 次元 (DIM5) までの出力とした. なお, 表中「専門家」は薬の専門家,「職人」は薬を調剤 する職人,「商人」は薬を扱う商人をさす。

Table 4. The Selected Contents of Counseling Card in Telephone Drug Counseling

\begin{tabular}{lr}
\hline \hline こちらの判断や意見を求めている & $: 572(65.5 \%)$ \\
情報や事実は求めているが, こちらの判断や意見までは求めていない & $: 259(29.7 \%)$ \\
ただただ聞いて欲しい・言いたい & $: 42(4.8 \%)$ \\
\hline & 合計 \\
\hline
\end{tabular}

注：患者・市民からの相談終了後，回答者は相談内容が上記 3 項目のいずれに該当したかを選択し，記録し た。上記は, 2002 年 4 月 1 日〜 7 月 13 日における集計結果.

談が終了するごとに，回答者は相談者の年齢，性 別, 相談内容, 相談時間などのほか, Table 4 に示 す「こちらの判断や意見を求めている」などの三肢 のうち，該当するもの 1 つを選択して記録した．今 回は, 2002 年 4 月 1 日〜 7 月 13 日における Table 4 の記録について集計を行った.

\section{調 査 結 果}

\section{1.「薬局薬剤師のイメージ像」等に関するアン} ケート調査

患者・市民に対する調査では 5188 件 (回収率 $37.1 \%$ ) の有効回答を得た。このうち, 協力の得ら れた薬局に来訪した患者からの回答は 1536 件 (回収 率 $38.6 \%$ ，協和発酵の社員・家族からの回答は 3652 件 (回収率 $36.5 \%$ ) であった。 また, 医師に対 する調查では 1045 件 (回収率 80.4\%), 薬局薬剤師 に対する調査では 1570 件 (回収率 4.6\%) の有効回 答を得た。これら合計 7803 件の回答の集計結果を Table 1 及び Table 2 に示した.

薬局薬剤師に対する調查の回収率が低かった主な 理由は, 調査票を冊子体（協和発酵の「薬立つ話」） に同封して配布したために, 調査が十分に周知され なかつたものと考えられる.この点については今後
の大きな課題であり, 以降の考察を進める上でも留 意しなければならない。同調査（全体）における回 答薬剂師の属性は，年齢が 20 代 $18 \%, 30$ 代 $29 \%$, 40 代 $29 \%, 50$ 代 $17 \%, 60$ 代 5\%，70 代以上 $2 \%$, また, 性別が男 $53 \%$, 女 $47 \%$ 。所属する薬局の状 況は, 1 日平均処方せ九応需枚数 126.3 枚, 1 力月 あたりの平均処方せん応需医療機関数 15.4 機関で あった.これらより, 調査客体の中においては極端 な偏りはないと思われたが, 回答者は医薬分業に参 加している薬局の薬剤師が主であると解釈すること が妥当であろう。なお, 回収率が低いため, 客体そ のものが今日の薬局薬剤師全体を代表したものであ ったかについては考慮を要する.

また，患者・市民に対する調査において，特定の 製薬企業の社員・家族が含まれた点にも留意する必 要がある. そこで, Table 2 の調査に関して協和発 酵の社員・家族からの回答のみを集計した結果, 「あまり信頼できない」15.6\%，「まあまあ信頼でき る」 $76.4 \%$ ，「十分信頼できる」 $8.0 \%$ となった。製 薬企業の社員・家族であることから薬局薬剤師に特 別好意的な回答をしたとは考えにくい. 他にも検討 しなければならない課題はあるが, 今回について は, 協力の得られた薬局に来訪した患者からの回答 


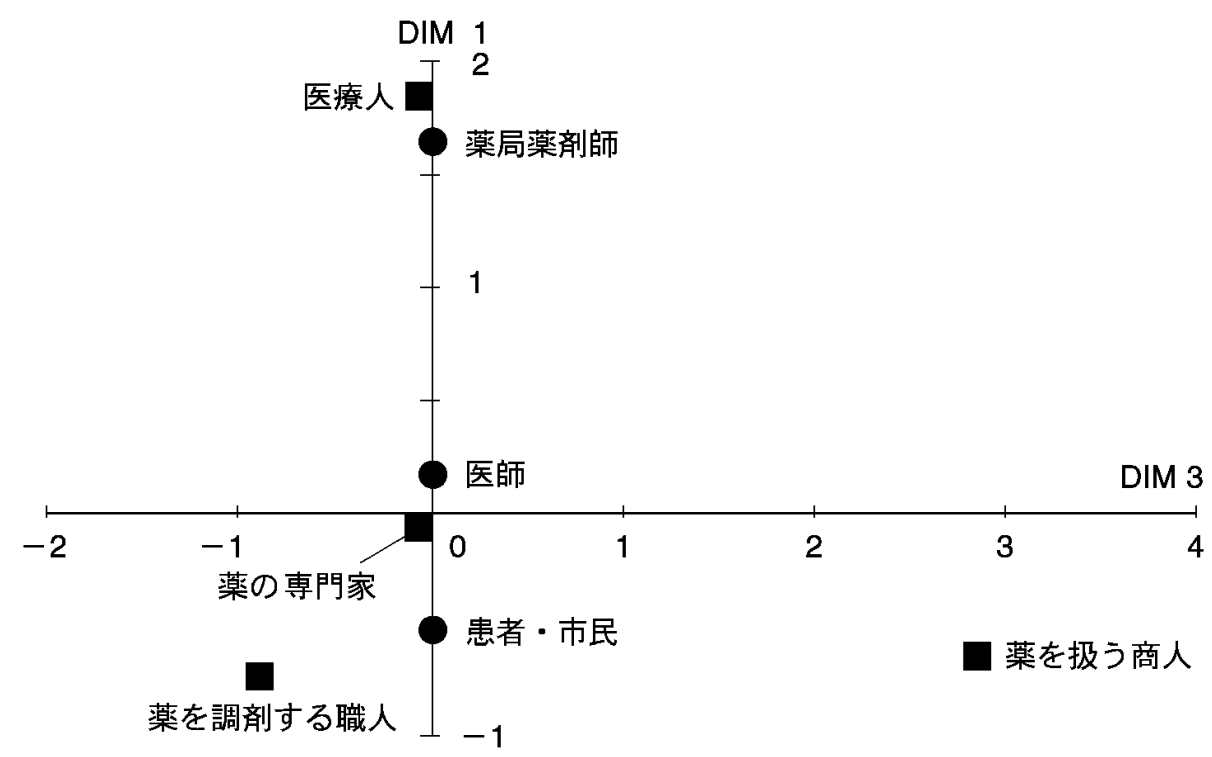

Fig. 1. The Configuration of 7 Items by Correspondence Analysis

と協和発酵の社員・家族からの回答を合わせて「患 者・市民」としてまとめ，考察を進めることとした.

コレスポンデンス分析の結果については, 説明率 とカテゴリースコアをTable 3 に，また，カテゴ リースコアの空間配置の例を Fig. 1 に示した.

コレスポンデンス分析は, 基本的には複数項目に わたるアンケートデータの結果（反応性）などを共 通性が出るように並べ替える作業である。しかし， 1 つの基準ですべてのデータを完全に並べ替えるこ とは困難なため, 通常は何らかの共通性のある次元 軸（DIM）が複数抽出される。 そして, 各々の次 元軸が原データのもつ情報の何\%を引き出せている かを示すものが説明率である，また，カテゴリース コアとは「項目」や「人」などの質的情報について, 「似たものどうし」が近い数值になるよう量的デー タに変換したものである.

今回の分析結果（Table 3) では, 説明率が最も 高い次元軸 (DIM1) において,「薬局薬剤師」と 「医療人」が際立つて近い関係にあることが観察さ れた。しかし, Table 1 では, 薬局薬剤師の項の 「薬の専門家」（675 件）と「医療人」（722 件）は他 と比べて近い回答数となっており，この点は DIM1 に反映されていない。一方, 説明率が三番目に高い 次元軸（DIM3）では「薬の専門家」と「医療人」 が近い数值になっていることから, Table 1 におけ る薬局薬剤師の項の「薬の専門家」と「医療人」の
関係は，ここに反映されたものと思われる.

\section{2. 日本薬剂師会の消費者電話薬相談における調} 査

調査期間において 873 件の記録を得た。集計結果 を Table 4 に示す.

\section{考察}

\section{1. 薬局薬剤師と広告}

1-1. 患者·市民や医師と薬局薬剤師の「視点の 違い」 Table 1 のよう，患者・市民や医師は, 薬局薬剤師を「薬の専門家」や「薬を調剤する職人」 とする回答が多かったが, 一方, 薬局薬剤師は自ら を「医療人」とする回答が最も多かつた. Fig. 1 で は，その結果を明確に把握することができる，Table 2 のように, 薬局薬剤師はかなり信頼されては いたが，それが「薬の専門家」や「薬を調剂する職 人」としての評価であるとすれば，自らを「医療人」 と回答した薬局薬剤師にとっては好ましい結果とは 言えない. また, 患者が「薬局薬剤師に, なぜ自分 の病名を聞かれなければならないのか」と感じた り，医師が「なぜ薬局薬剤師は，患者を不安に陥れ るような副作用のことを話すのか?」と不快に思う ことがしばしばあるという。この理由の 1 つとし て, 薬局薬剤師が自らを「医療人」と考える一方で, 患者や医師はそう思っていないという「視点の違い」 が挙げられるであろう。このために，日常の薬局業 
務においては, 薬剤師側の自己認識の違いに起因す る患者や医師との「すれ違い」が頻繁に発生してい ることも容易に想像される。

筆者は, 以前, 日本薬剤師会における消費者電話 薬相談の相談項目（全 15 分類）についてコレスポ ンデンス分析を行い, その結果,「効能・効果」「用 法・用量」「有害作用の心配」「有害作用の発現」 「相互作用」の 5 項目は相談者（患者・市民）にと つて区別されておらず，「1グループ」であること を報告した. ${ }^{3)}$ 薬劑師はこれら 5 項目を当然のよう に区別していることから，患者・市民と薬剤師の間 には明らかに「視点の違い」があると思われた。今 回は，このことを別の角度から確認したとも言える.

患者・市民や医師と薬局薬剤師の間にこのような 「視点の違い」が存在することは, 調剤において 「すれ違い」が発生するばかりではない。厚生労働 省は, 健康を積極的に増進し, 疾病を予防する「一 次予防」に重点を置いた対策の推進が急務であると 考えて，2000 年度より「21 世紀における国民健康 づくり運動（健康日本 21)」を開始した。ここでは, 薬局薬剂師が医薬品の適正使用や健康づくりに関す る相談に応じること, また, これらの情報提供を行 うことなどが期待されている. ${ }^{4)}$ 例えば，喫煙や飲 酒の問題, 健康関連機器や特定保健用食品の使用な どについて幅広く対応することが求められており, この際，三者間に「視点の違い」があれば大きな障 害となるであろう。そのためにも，このような「視 点の違い」について薬局薬剤師は今まで以上に注目 し，これの是正に努める必要があると言える.

1-2. 薬局薬剤師における広告の意義 広告と は，販売を目的とした商業広告ばかりではない。 小 林によれば，広告とは「人が人に対してある意図を もって訴えかけること」であり, それは政治, 宗 教，教育の世界などでも使われている5)としてい る。そうであれば，薬局薬剤師が患者・市民に対し て「医薬品の適正使用」や「健康づくり」という意 図をもって訴えかけることは広告そのものである. したがって, 本稿では「広告」という言葉を, もっ ぱら自己アピールの宣伝道具としてだけではなく, 薬局薬剤師の活動の方法としてとらえる.

2000 年 3 月に報告された日本 RAD一AR 協議会 の一般市民を対象とした調査によれば，「お薬手帳」 の認知度は $12 \%$,「薬歴」については $37 \%$ という結
果であった. ${ }^{6}$ 薬局薬剤師の仕事内容は, 社会に十 分知られているとは言い難い。そこで, 薬局薬剤師 が患者・市民や医師と違つた自らのイメージ像をも つていたことについては, 薬局薬剤師の日頃の広告 が不十分であることが一因として挙げられる。

小林は，いつの時代でも広告には「売りのコミュ ニケーション」という変わらない前提があり, モノ を買ってもらうためには，売り手と買い手の間の心 情的なつながりが重要である7)としている。ここで 用いられる「売り」とは販売のみならず「顔を売る」 という意味も含まれ，また，「モノ」とは商品のみ ならずサービスなども含まれると考えられる。ささら に小林は，広告の送り手は受け手の反応を見ながら 訴え方を修正するが，これが繰り返えされることに より，送り手が受け手に妥協することで均衡が保た れるようになる5)とも述べている。 このような均衡 状態に達したときには, 当然, 受け手側も広告の影 響により変化しているに違いない。 そこで, もし患 者・市民, 医師, 薬局薬剤師の三者間の「視点の違 い」が是正されるとすれば，例えば Fig. 2 のよう に，三者の認識がともに変化した状態にたどり着く と考える.しかし，薬局薬剂師が自らを「医療人」 として固執し続けるならば，患者・市民や医師との 間に心情的なつながりは生まれにくく, Fig. 1 にお ける三者間の距離は容易に縮小しないであろう。薬 局薬剤師が自らを「医療人」として考えることを完 全に捨て去る必要はないが，患者・市民や医師との かかわりの中において, 自らも変化していくという 意識が必要と思われる。

薬局薬剂師が「医薬品の適正使用」や「健康づく り」についての広告を行うとき, 課題となるのは, Fig. 2 のような変化を念頭に置いた, 患者・市民や 医師への訴えかけ方であろう。相手の目線に立つこ とは当然であるが，上述のように，自己の認識を変 える柔軟さも必要である。 さらには, 患者・市民を $「 1$ つの存在」として捉えることなく，どのような 語りかけをすれば，どのようなタイプの患者・市民 が耳を傾けてくれるであろうかという研究も必要と 思われる。

\section{2. 薬局薬剤師の「情報提供」と「心配 · 不安の 相談」}

今回のアンケート調査（患者・市民対象）の別項 において，薬について第三者機関へ相談した経験が 


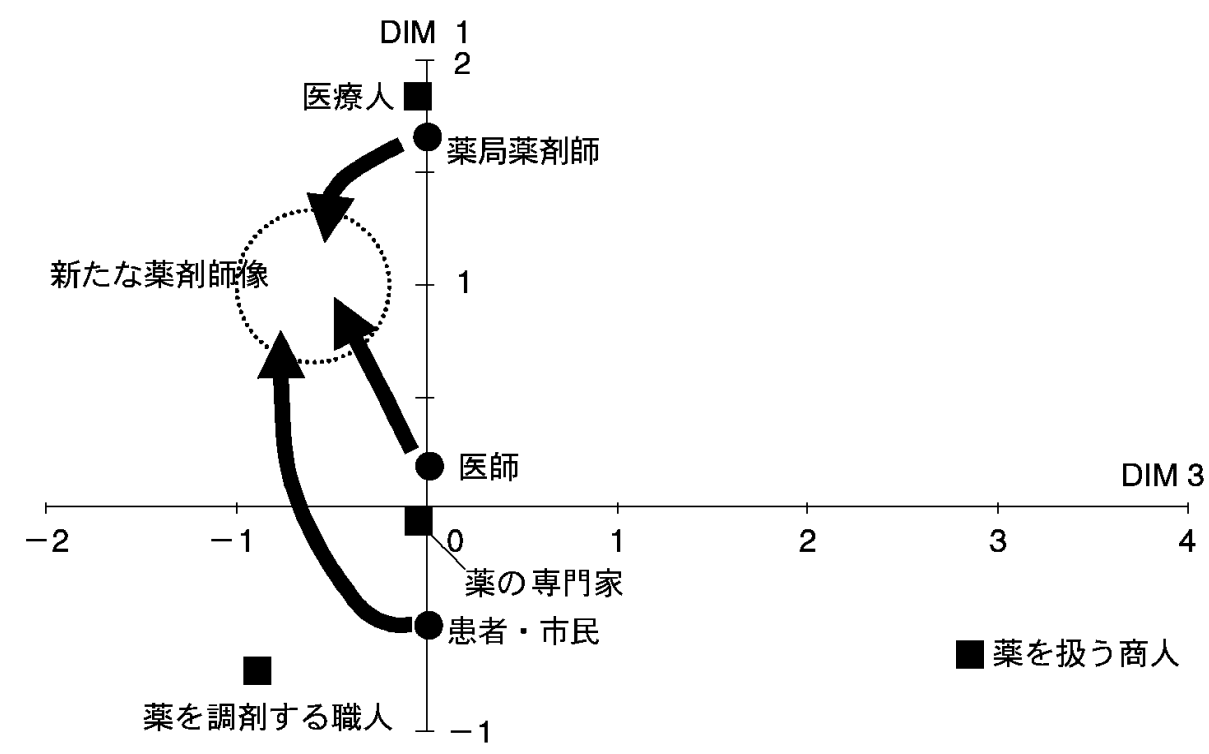

Fig. 2. A Shift to New Image of Community Pharmacists

ある人に対して，なぜ相談することにしたのかを質 問したところ，「薬や病気について，もつと詳しい 情報を入手するため」 $60 \%$ ，「病気や薬などに関す る心配・不安の相談のため」57\%,「第三者の意見

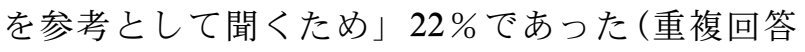
可). ${ }^{8)}$ そこで, 薬局薬凨師が患者・市民と接する場 合にも,「情報提供」と「心配・不安の相談」の 2 つのテーマを考えてよいと判断した．本項ではこの 二者について考察する.

\section{2-1. 薬局薬剤師と「情報提供」薬局薬剂師} は, 薬剤師法第 25 条の 2 による「情報提供義務」 や保険調剂上の評価などにより, 患者に対して書面 などによる薬の情報提供を行っている. 患者の評判 もよいが，ここには「薬局薬剤師が，このような サービスを提供しているとは思っていなかった」と いう意外性による評価 ${ }^{9)}$ も含まれることに着目した い.

嶋口によれば，顧客の満足は「顧客が抱く購買前 の期待の大きさ」と「購買後の客観的評価」との相 対によって心理的にその水準が決まる10)としてい る. 日頃, われわれが「思ったより, よかった」と か「あれは，期待はずれだつた」などと何気なく会 話していることを思えば，これは理解できることで ある．すなわち「事前の期待」と「事後の結果」の 想いのギャップで満足・不満足は決まると言える. これを踏まえると, まずは薬局薬剤師が提供する情 報の内容が患者の満足度を左右することであろう。
しかし，いずれ患者が薬局での情報提供を当然と思 うようになれば，薬局薬剤師がある程度のレベルの 情報提供をしていたとしても，意外性に基づく患者 満足は得られにくくなると考える。

嶋口は，企業が提供する有形・無形のサービスを 「本質サービス」と「表層サービス」に二分し，前 者は「代価に対して当然受けうると期待するもの」, 後者は「代価に対して必ずしも当然と思わないが, あればあるにこしたことはないもの」とした，その 上で, 本質サービスは, 企業がその本質サービス属 性をある最低許容水準以下のレベルにしてしまう と, その満足はゼロ以下（すなわち, 怒りや抗議を 伴う状態）になってしまう。一方, 表層サービス は，それらを充実させていくと，次第に満足水準が 上昇してくる10)としている.

患者への情報提供は，現状では表層サービスであ るが，いずれは本質サービスに転換すると予想され る，そのような状況になったとき，万一，患者への 情報提供が中断されるようなことになれば，患者の 怒りや抗議を招くことになる。したがって，今日， 薬局薬剂師が患者への情報提供を開始した以上, 薬 剤師側の都合でそのサービスを中断することは, 社 会的にも容認されない状況になると思われる.

2-2. 薬局薬剤師と「心配 · 不安の相談」薬 剂師法において, 薬剤師が調剂した薬について情報 提供を行うことは義務であるが，患者の QOL (quality of life) や健康への心配・不安の相談にの 
ることは規定されていない。また，薬局は医薬品の 小売業者としても位置づけられている。これらのこ とから, 薬局薬剤師が患者のさまざまな相談にのる ことは，今日のところ「代価に対して必ずしも当然 とは思わないが，あればあるにこしたことはないも の」と考えられ，まさに表層サービスに分類される ものと言える.

日本薬剤師会の消費者電話薬相談において集計を 行つた結果， Table 4 のとおり，多くの相談者は薬 剂師に「判断や意見」，すなわちアドバイスを求め ていた。これは，薬凨師に対する患者・市民のニー ズが，もはや情報提供に留まらず，心配・不安の相 談などに移行しつつあることを示す。その一因とし ては，今日，薬に関する書籍が多数販売されている ことやインターネットの普及により，情報入手が容 易になったことが挙げられる.

表層サービスが顧客の満足水準を上昇させること を合わせて考えれば，今後の薬局薬剤師の社会的役 割も「情報提供」から「心配・不安の相談」へとシ フトしていくものと予想される。これは，薬剤師の 職能の変化としてもとらえることができる，薬局薬 剤師が調剂という枠の中で，薬の情報提供の夕しか 行わないでいるならば，Fig. 1 に示すような相互認 識の違いはさらに拡大すると考えられる，患者・市 民の健康などに対する心配や不安を, 患者の視点で 共有することが求められている.

筆者は, 以前, 日本薬剤師会の消費者電話薬相談 において，「相談前の不満度」と「相談後の満足度」 の関係を検討した。 その結果，相談前の不満は「怒 りや抗議を伴う満足がマイナスのもの」(dissatisfaction）よりも「満足がゼロ状態にあるもの」 （unsatisfaction）のほうがはるかに多く, 後者は単 に満足していないだけであることから, 容易に満足

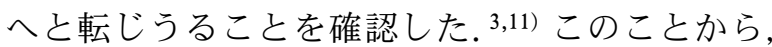
些細な心配・不安ほど, 対応によってより大きな満 足が得られると言える。薬局薬剤師も「小さなこと でも気軽に相談にのる」という姿勢を常にもてば, 患者満足を大幅に上昇させることができると考える.

\section{3. 薬局薬剤師と医薬品流通}

薬局薬剤師は, 処方せん調剂を通して患者や医師 と係わるだけでなく, 医薬品流通の中で医薬品卸売 販売業者 (以下, 医薬品卸とする.) などとも社会 的な関係をもつ. 本項では, その意義について考察
する.

医薬品流通については，1990 年の医薬品流通近 代化協議会の報告や日米構造問題協議最終報告, さ らには，1991 年の公正取引委員会による独禁法力゙ イドラインなどにより新仕切価制度が導入され, 従

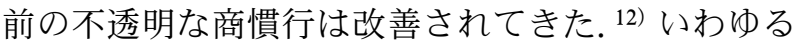
「流通改革」と呼ばれるものであるが，井上らは， これにより医療機関の利潤（薬価差益）が減少し, 医薬品卸と医療機関との関係は新たな局面を向かえ ている13) としている. しかし, 流通の問題は, 医薬 分業下の薬局にもけっして無縁のものではない.

三村は, 医薬分業の進展が医薬品卸に全く新しい 経営問題を発生させているとし, 具体的には, 受注 数量の小口化, 納品の多頻度化, 緊急発注の頻発な ぞを挙げている，さらに，医療用医薬品は，患者へ の処方と調剂, 服薬指導, 副作用や相互作用のチェ ックなどの一連の過程を通して価值実現が図られる ものであり, そのため, 供給側だけでなく患者まで を巻き込んだ一連の過程をマネジメントしていく必 要がある，品質管理は工場段階では終了せず，流通 段階, 患者との接点, そして患者の使用過程まで包 括したクオリティ管理の仕組みが必要になる14) と述 ベている.

今日, 医薬品卸の経営は, 薬価差益の縮小や医療 機関との価格交渉激化などにより悪化しているとさ れるが，三村の指摘などを踏まえると，再生のため のシナリオは単なる経営の合理化・効率化だけでは 不十分であろう。医薬品卸の経営には, 直販や系列 卸の存在など, 従来より製薬企業の意向が強く存在 していた. しかし, 今後は彼らの顧客である薬局や 医療機関との関係にも一層目を向け，価格交渉や商 品納入には留まらない新たな関係を構築することが 必要になるであろう。この動きは，すでに医薬品卸 のクラヤ三星堂が行っている “KS DEM” (Kuraya Sanseido Drug Event Memo）などにおいて見ること

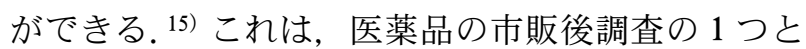
して, 同社が薬局や医療機関から副作用等のイベン 卜を収集し，製薬企業に報告するとともに，これを 取りまとめた上で現場にもフィードバックするもの である，単に医薬品というモノだけの取引に留まら ず，それに伴う情報も扱うことで, 顧客との関係に 新たな意義を付加するものとして注目される．この ように, 今後, 医薬品流通業界においては「製薬企 
業一医薬品卸一薬局」間での機能的な垂直的統合 (vertical integration)がさらに進むものと思われる.

また，医薬品流通業界では，垂直方向のみなら ず，水平方向での機能的統合の動きも見られる．日 本薬剤師会では，1999 年医薬分業統括支援システ ム (Iyaku-Bungyo Integrated Support System: IBISS) の実証実験を行つた。内容はデー夕標準化を基礎と して, 薬局の医療情報の共用化や最新情報の取り込 み, 副作用情報の吸い上げなどを実施し, 医薬分業 の総合的支援の可能性を検証するものであった．具 体的には，モデル地区内において，患者に服用中の 薬や特異体質などを記録したフロッピーディスクを 配付し, 別の薬局で調剂を受けたり, 大衆薬を購入 する際にそれを任意に提示してもらうことで，薬局 間の連携が取れるか否かを確認した。結果として, 薬局間のデー夕の標準化・情報の共用化についての

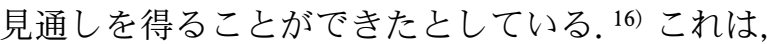
「薬局一薬局」間における水平的統合（horizontal integration）の 1 つとしてとらえることができる.

医薬品流通業界では，すでに標準的医薬品コード （HOT 番号）も使用され始め, ${ }^{17)}$ 今後はますます物 流と医薬品情報とを合わせた機能面での垂直的統 合・水平的統合が進むものと思われる。ここにおい て着目すべきことは，この中で誰が強いパワーを発 揮するかである。それが判明するには今後しばらく の時間を要するが，すべてが商業べースで進むこと があってはならず，そこには「医療」あるいは「患 者のため」という要素も必要であろう。医薬分業の 進渉により, 薬局薬剤師は患者に最も近い存在の一 人となってきたことから，製薬企業や医薬品卸に 「医療の担い手」としての意見を述べ，また，現場 で得られた情報を発信することが求められる，さら に薬局同士，あるいは薬局と医療機関との間では情 報を共用し，患者の治療に一層貢献するための活動 も求められる。薬局薬剤師には, 医薬品流通の世界 において他の一般消費財の流通には見られない独自 の視点や情報を提供する役割があると言える.

\section{結語}

本研究では, 社会における薬局薬剤師の役割につ いて, 広告研究, マーケティング, 流通論の各視点 から検討した。また，議論に資するため，「薬局薬 剤師のイメージ像」に関する解析ではコレスポンデ
ンス分析を用い，患者・市民，医師，薬局薬剤師の 三者の関係を同時に把握することを試みた。

薬局薬剂師は，現状，患者・市民や医師とは離れ た認識をもっていることを明らかにし，医薬品の適 正使用や患者・市民の健康づくりに貢献するために は，環境に合わせて自らの意識を柔軟に変える姿勢 が必要であると考えた。また，顧客満足の視点か ら，薬局薬剤師の情報提供は，いずれは本質サービ スとして位置づけられることを予測し，その一方 で，患者・市民の心配や不安の相談にのることは表 層サービスとして社会から望まれていることを明ら かにした。ささに，流通論に関する文献調査を通し て，医薬品流通業界が機能面において垂直的統合・ 水平的統合に向かいつつあることを展望し，この中 で薬局薬剤師は薬の専門家，あるいは医療人として 独自の意見や情報を提供すべき存在であることを確 認した。

医薬分業が急速に進渉する中, 薬局薬剂師は単に 目前の院外処方せんを調剂し，患者へ薬を渡すだけ では社会的に認められない状況にあると言える。本 研究では, このことを主に経営学の角度から概観し たが，しかし薬局薬剤師を取り巻く世界には医療の 倫理など特有の環境や条件もあり，さらに検討すべ き余地があると思われた。 今後は，これらも合わせ て一層の議論が必要と考える.

謝辞「薬局薬剤師のイメージ像」に関するア ンケート調査のデータを使用することに快諾を頂い た, 協和発酵工業株式会社 医薬営業部の早瀬孝彦 氏に感謝いたします。

\section{REFERENCES}

1) Yamada H., Shimamori Y., Hongo F., Sato S., Hayase Y., Jpn. J. Pharm. Health Care Sci., 27, 331-336 (2001).

2) "Nyumon Tahenryo-Kaiseki no Jissai," ed. by Asano H., Kodansha-Scientific., Tokyo, 2000, pp. 27-39.

3) Hayashi S., Mukai T., Watanabe T., Journal of the Japan Pharmaceutical Association, 53, 1161-1169 (2001).

4) Textbook of "Kenko-Nippon 21," Japan Pharmaceutical Association, 2002.

5) “Koukoku, Mouhitotsu no Kagaku," ed. by 
Kobayashi Y., Jikkyo-Shuppan., Tokyo, 1982, pp. 3-10.

6) Report, RAD-AR Council, Japan (2000).

7) “Sin-Kachi Souzou no Komyunikeishon," ed. by Kobayashi Y., Hikita S., Wada M., Kamei A., Diamond-sha, Tokyo, 1997, pp. 10-12.

8) “Yakudatsu Hanashi No. 33," Kyowa Hakko Kogyo Co., Ltd., Tokyo, 2001, p. 15.

9) Kiyou N., 9th Clinical Pharmacy Symposium in Kumamoto, 2001, pp. 97-101.

10) "Kokyaku-Manzoku-Gata Makethingu no Kouzu," ed. by Shimaguchi M., Yuhikaku, Tokyo, 1994, pp. 64-78.

11) Hayashi S., Mukai T., Watanabe T., Pharmaceutical Library Bulletin, 45, 232-236
(2000) .

12) "Iryou-Iyakuhin-Gyokai no Ippan-Chisiki," ed. by Yakuji-Keizai Kenkyukai., Jiho-sha., Tokyo, 2001, pp. 41-49.

13) Inoue T., Tezuka K., Iryo-Keizai Kenkyu, 11, 5-21 (2002).

14) Mimura Y., Iryou to Shakai, 11(2), 1-27 (2001).

15) KS DEM Report, Kuraya Sanseido Inc. (2002).

16) Kouno Y., Urushibata M., Rx Info., 6, 16311637 (2000).

17) Tsuchiya F., Nichiyaku Iyakuhin Jyoho, 4 (2), 14-18 (2001). 